\title{
PEMANFAATAN MEMBRAN NATA DE COCO SEBAGAI MEDIA FILTRASI UNTUK REKOVERI MINYAK JELANTAH
}

\author{
Senny Widyaningsih dan Purwati \\ Program Studi Kimia, Jurusan MIPA, Fakultas Sains dan Teknik UNSOED \\ Email : sennysetiadi@yahoo.com
}

\begin{abstract}
ABSTRAK
Peningkatan kualitas minyak jelantah telah dilakukan dengan metode filtrasi menggunakan membran selulosa bakterial yang terbuat dari nata de coco. Pembuatan membran nata de coco dilakukan dengan cara memurnikan nata de coco hasil proses fermentasi bakteri Acetobacter xylinum. Karakterisasi membran meliputi berat jenis, nilai fluks, dan koefisien rejeksi. Proses filtrasi minyak jelantah menggunakan tekanan sebesar 4 $\mathrm{kgf} / \mathrm{cm}^{2}$ dengan metode dead-end. Hasil penelitian menunjukkan bahwa karakterisasi membran nata de coco memiliki berat jenis sebesar $0,6314 \mathrm{~g} / \mathrm{cm}^{3}$, nilai fluks air sebesar $104,021 \mathrm{~L} / \mathrm{m}^{2}$.jam, fluks minyak sebesar $1,004 \mathrm{~L} / \mathrm{m}^{2}$.jam dan fluks Dekstran T-500 sebesar $52,208 \mathrm{~L} / \mathrm{m}^{2}$.jam. Nilai rejeksi membran sebesar $15,11 \%$. Peningkatan kualitas minyak jelantah dibanding sebelum rekoveri dapat dilihat dari penurunan angka asam sebesar $54,95 \%$, kadar air sebesar $93,22 \%$, serta peningkatan angka penyabunan sebesar $29,09 \%$ dan angka iod sebesar 8,14\%.
\end{abstract}

Kata kunci: membran, nata de coco, minyak jelantah.

\section{UTILIZATION OF NATA DE COCO MEMBRANE AS A FILTRATION MEDIUM FOR WASTED COOKING OIL RECOVERY}

\begin{abstract}
Purification process of wasted cooking oil had been done by filtration method using bacterial cellulose membrane made from nata de coco. Nata de coco membrane preparation had been done by purifying nata de coco resulted from bacterial fermentation of Acetobacter xylinum. Membrane nata de coco was applied as filtration media for the recovery of wasted cooking oil. The filtration process uses a pressure of $4 \mathrm{kgf} / \mathrm{cm}^{2}$ using dead-end method. The results showed that the characterization of membrane nata de coco has a density of $0.6314 \mathrm{~g} / \mathrm{cm}^{3}$, the value of water flux was $104.021 \mathrm{~L} / \mathrm{m}^{2} . \mathrm{h}$, oil flux was $1.004 \mathrm{~L} / \mathrm{m}^{2} . \mathrm{h}$ and flux of dextran T-500 was $52.208 \mathrm{~L} / \mathrm{m}^{2} . \mathrm{h}$. The rejection was $15.11 \%$. The quality of wasted cooking oil after recovery was increase according to decreasing of acid number and water content i.e. $54.95 \%$ and $0.059 \%$, and increasing saponification number and iod number i.e. $29.09 \%$ and $8.14 \%$.
\end{abstract}

Keywords: membrane, nata de coco, wasted cooking oil. 


\section{PENDAHULUAN}

Minyak jelantah adalah minyak goreng yang telah dipakai berulang kali untuk menggoreng bahan pangan. Secara fisik, minyak jelantah berwarna kecoklatan, kental dan berbusa. Hal ini terjadi karena adanya kerusakan pada minyak yang digunakan. Kerusakan ini akan mempengaruhi mutu bahan pangan yang digoreng. Minyak yang rusak ini diakibatkan adanya proses oksidasi dan polimerisasi yang menghasilkan bahan pangan dengan rasa dan bau yang tidak enak. Apabila minyak jelantah digunakan secara berkelanjutan dapat merusak kesehatan manusia, menimbulkan penyakit kanker dan akibat selanjutnya dapat mengurangi kecerdasan.

Pertumbuhan jumlah penduduk dan perkembangan industri, restoran dan usaha fastfood menghasilkan minyak jelantah dalam jumlah yang cukup tinggi (Dalimunthe, 2008). Kebanyakan rumah tangga membuang minyak jelantah hasil penggorengan ke dalam saluran air dalam rumah. Pembuangan minyak jelantah ke lingkungan dapat menyebabkan terjadinya pencemaran. Akibat dari pembuangan ini, maka kandungan minyak dalam sungai akan tinggi. Tingginya kandungan minyak ini dapat menyebabkan oksigen terlarut tidak dapat masuk ke dalam air karena sirkulasi oksigen terganggu sehingga kandungan oksigen di air turun dan dapat membahayakan kehidupan hewan di dalam air.

Penelitian mengenai pemanfaatan minyak jelantah telah banyak dilakukan. Salah satunya adalah untuk pembuatan biodiesel. Biodiesel digunakan sebagai pengganti minyak solar. Biodiesel memiliki keunggulan dibanding minyak solar, yaitu tidak menambah jumlah karbondioksida dalam udara sehingga dapat mengurangi polusi udara. Pemanfaatan lainnya adalah dengan dijadikan produk sabun seperti yang telah dilakukan oleh Dalimunthe (2008). Minyak jelantah dapat dijadikan sabun karena memiliki kandungan lemak yang cukup banyak. Minyak jelantah ini direaksikan dengan sejumlah basa sehingga terbentuk sabun.

Produk-produk pemanfaatan tersebut masih memiliki kekurangan dibandingkan bila menggunakan bahan baku dari minyak goreng baru. Proses pemurnian diperlukan untuk meningkatkan kualitas minyak jelantah agar ketika dimanfaatkan dapat menghasilkan produk yang lebih baik. Beberapa cara telah dilakukan untuk meningkatkan kualitas minyak jelantah, diantaranya menggunakan arang aktif, abu sekam padi dan abu terbang. Pemurnian minyak jelantah dengan menggunakan adsorben mempunyai kelemahan karena memungkinkan partikel-partikel adsorben tertinggal di dalam minyak sehingga sulit dipisahkan.

Alternatif lain pemurnian minyak jelantah adalah mengolah minyak jelantah dengan metode filtrasi menggunakan membran selulosa bakterial yang terbuat dari nata de coco. Membran berfungsi memisahkan material berdasarkan ukuran dan bentuk molekul, menahan komponen dari umpan yang mempunyai ukuran lebih besar dari poripori membran dan melewatkan komponen-komponen yang mempunyai ukuran lebih kecil. Filtrasi dengan menggunakan membran selain berfungsi sebagai sarana pemisahan juga berfungsi sebagai sarana pemurnian dari suatu larutan yang dilewatkan pada membran tersebut (Agustina, dkk, 2008).

Teknologi membran memiliki banyak keunggulan yang tidak dimiliki oleh metode-metode pemisahan lainnya. Keunggulan pemisahan dengan membran, yaitu tidak membutuhkan zat kimia tambahan dan memiliki kebutuhan energi yang relatif rendah (Miyagi et al., 2003). 
Nata de coco adalah hasil proses fermentasi air kelapa dengan mikroorganisme Acetobacter xylinum. Nata pada dasarnya merupakan selulosa, apabila dilihat di bawah mikroskop akan tampak sebagai suatu massa fibril tidak beraturan yang menyerupai benang atau kapas (Sutarminingsih, 2004). Menurut Krystinowicz (2001), selulosa bakterial sebagai membran mempunyai beberapa keunggulan antara lain kemurnian tinggi, mempunyai kerapatan antara 300 dan $900 \mathrm{~kg} / \mathrm{m}^{3}$, kekuatan tarik tinggi, elastis dan terbiodegradasi.

Hasil penelitian terdahulu mengenai membran selulosa bakterial menunjukkan bahwa membran ini mempunyai kecepatan permeasi yang lebih besar dibanding dengan selulosa teregenerasi (selofan) (Piluharto, 2003). Berdasarkan sifat fisik dan kimia yang dimiliki oleh selulosa bakterial, diperlukan suatu penelitian tentang kemungkinan penggunaan selulosa bakterial sebagai membran pemisah untuk pemurnian minyak jelantah.

\section{METODE PENELITIAN}

\section{Alat dan Bahan}

Alat-alat yang digunakan dalam penelitian ini adalah alat gelas yang biasa digunakan, nampan plastik, sel ultrafiltrasi, kertas $\mathrm{pH}$, oven, hand-press, pengaduk magnetik, dan desikator.

Bahan-bahan yang digunakan dalam penelitian ini adalah air kelapa, gula pasir, asam asetat glasial, aquades, starter Acetobacter xylinum, minyak jelantah, $\left(\mathrm{NH}_{4}\right)_{2} \mathrm{SO}_{4}, \mathrm{NaOH}$, amilum, $\mathrm{Na}_{2} \mathrm{~S}_{2} \mathrm{O}_{3}$, phenolphthalein, $\mathrm{HCl}$, etanol $95 \%$, KOH, dan KI.

\section{Prosedur Kerja}

\section{a. Pembuatan Nata de coco}

Media fermentasi dalam pembuatan nata de coco terdiri atas air kelapa sebanyak 1 L dididihkan lalu ditambahkan 6,7 g gula pasir dan $5 \mathrm{~g}$ $\left(\mathrm{NH}_{4}\right)_{2} \mathrm{SO}_{4}$. Media didinginkan dan $\mathrm{pH}$ media diatur hingga mencapai 4 dengan menambahkan asam asetat glasial, kemudian dinokulasi dengan starter dan diinkubasi selama 8 hari.

\section{b. Pembuatan Membran Nata de coco}

Bentuk nata de coco hasil fermentasi berupa gel dicuci dengan air mengalir selama 24 jam. Gel dicuci dengan $\mathrm{NaOH} 2 \%$ selama 1 jam pada suhu $80-90{ }^{\circ} \mathrm{C}$. Terakhir dicuci kembali dengan air sampai $\mathrm{pH}$ netral. Gel yang telah dimurnikan lalu ditekan dengan alat hand-press hingga diperoleh membran nata de coco. Film yang diperoleh kemudian dikeringkan pada suhu kamar $\left( \pm 27-30{ }^{\circ} \mathrm{C}\right)$ dan diperoleh membran nata de coco kering.

\section{c. Karakterisasi Membran}

\section{Uji berat jenis}

Pengujian berat jenis dilakukan dengan menimbang film kering nata decoco, kemudian hasilnya dibagi dengan volume kering. Penentuan volume dilakukan dengan perkalian luas $\mathrm{x}$ tebal film.

\section{Uji fluks}

Film yang diperoleh kemudian dipotong berbentuk lingkaran. Ukuran lingkaran disesuaikan dengan desain alat ultrafiltrasi. Penentuan fluks air diperoleh dengan mengukur banyaknya volume air yang melewati tiap satuan luas permukaan membran per satuan waktu. Fluks volume dinyatakan sebagai berikut:

$\mathrm{J}=\frac{\mathrm{V}}{\mathrm{A.t}}$

dimana:

$\mathrm{J}=$ fluks volume $\left(\mathrm{L} / \mathrm{m}^{2}\right.$ jam $)$

$\mathrm{A}=$ luas permukaan $\left(\mathrm{m}^{2}\right)$ 
$\mathrm{T}=$ waktu (jam)

$\mathrm{V} \quad=$ volume permeat $(\mathrm{L})$

\section{Uji rejeksi}

Membran dikarakterisasi dengan mengukur koefisien rejeksi terhadap larutan uji Dekstran T-500. Koefisien rejeksi dihitung dengan persamaan sebagai berikut :

$\mathrm{R}_{\mathrm{M} 1}(\%)=1-\frac{\mathrm{C}_{\mathrm{Ml} \text { (permeat) }}}{\mathrm{C}_{\mathrm{Ml} \text { (feed)s }}} \times 100$

dimana:

$\mathrm{R}=$ koefisien rejeksi

$\mathrm{C}_{\mathrm{MI}} \quad=$ konsentrasi permeat

$\mathrm{C}_{\mathrm{MI}}=$ konsentrasi umpan

Penentuan koefisien rejeksi diukur dengan metode spektrofotometri dimana larutan dekstran bagian permeat dan umpan ditambah fenol $5 \%$ dan $\mathrm{H}_{2} \mathrm{SO}_{4}$ pekat dengan perbandingan 1:1:5 dan diencerkan dalam labu ukur $10 \mathrm{~mL}$. Absorbansi permeat dan konsentrat diukur pada $\lambda=490 \mathrm{~nm}$ dengan spektrofotometer.

\section{d. Uji Kualitas Minyak}

Uji ini dilakukan sebelum dan setelah minyak dilewatkan pada membrane nata de coco. Uji ini meliputi:

\section{Penentuan bilangan asam}

Sebanyak 20 gram minyak dimasukkan ke dalam Erlenmeyer dan ditambahkan $50 \mathrm{~mL}$ alkohol $95 \%$. Campuran tersebut kemudian dipanaskan sampai mendidih dan dikocok sampai larut. Larutan yang sudah dingin kemudian dititrasi dengan larutan $\mathrm{KOH}$ standar 0,1 $\mathrm{M}$ dengan memakai beberapa tetes indikator phenolphthalein (PP). Titik akhir titrasi tercapai apabila terbentuk warna merah muda pada larutan yang tidak hilang selama 0,5 menit.

\section{Uji kadar air}

Sebanyak 1 gram minyak goreng dipanaskan dalam oven pada suhu 105 ${ }^{\circ} \mathrm{C}$ selama 1 jam. Minyak kemudian didinginkan dalam desikator selama 15 menit dan ditimbang, selanjutnya dipanaskan lagi dalam oven dengan suhu yang sama selama 30 menit lalu didinginkan dalam desikator selama 15 menit dan ditimbang. Perlakuan ini diulangi sampai tercapai berat konstan.

\section{Penentuan angka iodium}

$\begin{array}{rrrr}\text { Sebanyak } & 1,25 & \text { gram minyak } \\ \text { goreng dimasukkan } & \text { ke } & \text { dalam }\end{array}$ Erlenmeyer bertutup, lalu ditambahkan 5 $\mathrm{mL} \mathrm{I}_{2}$ dan dibiarkan di tempat gelap selama 30 menit dengan sesekali dikocok, kemudian ditambahkan $3 \mathrm{~mL}$ larutan KI 15\% dan $25 \mathrm{~mL}$ aquades yang telah dimasak dan didinginkan. Larutan selanjutnya dititrasi dengan larutan $\mathrm{Na}_{2} \mathrm{~S}_{2} \mathrm{O}_{3} \quad 0,005 \quad \mathrm{M}$ sampai larutan berwarna kuning pucat, selanjutnya ditambahkan $2 \mathrm{~mL}$ larutan amilum. Titrasi dilanjutkan sampai warna biru tepat hilang. Larutan blanko dibuat dari $5 \mathrm{~mL} \mathrm{I}_{2}$ ditambahkan $3 \mathrm{~mL}$ KI $15 \%$ diencerkan dengan $25 \mathrm{ml}$ aquades yang telah dimasak dan didinginkan, selanjutnya dititrasi dengan larutan $\mathrm{Na}_{2} \mathrm{~S}_{2} \mathrm{O}_{3}$ 0,005 M.

\section{Penentuan bilangan penyabunan}

Minyak ditimbang seberat kurang lebih 5 gram dalam erlenmeyer. Minyak ditambahkan $\mathrm{KOH} \quad 0,5 \mathrm{M}$ alkoholik sebanyak $50 \mathrm{~mL}$. Sesudah ditutup dengan pendingin selanjutnya dididihkan sampai minyak tersabunkan secara sempurna ditandai dengan tidak terlihat butir-butir lemak atau minyak lemak dalam larutan. Minyak didinginkan kemudian dititrasi dengan $\mathrm{HCl} 0,5 \mathrm{M}$ menggunakan indikator phenolphtalein. Titik akhir titrasi ditandai dengan tepat hilangnya warna merah. Blanko dibuat seperti perlakuan diatas hanya tanpa 
sampel. Titrasi blanko ini menunjukkan $\mathrm{KOH}$ mula-mula yang digunakan dalam reaksi penyabunan.

\section{HASIL DAN PEMBAHASAN}

\section{Nata de coco}

Air kelapa yang digunakan untuk membuat nata de coco bukan air kelapa segar tapi air kelapa yang telah dibasikan atau ditunda. Air kelapa yang dibasikan dapat menghasilkan rendemen nata de coco yang lebih tinggi daripada air kelapa segar (Sutarminingsih, 2004). Proses penundaan juga bertujuan untuk menghemat pemakaian asam asetat glasial karena selama penundaan terjadi fermentasi yang menghasilkan asam sehingga menurunkan $\mathrm{pH}$ air kelapa.

Penambahan gula pasir berfungsi sebagai sumber karbon atau energi untuk bakteri Acetobacter xylinum. Penambahan $\left(\mathrm{NH}_{4}\right)_{2} \mathrm{SO}_{4} \quad$ berfungsi sebagai sumber nitrogen yang dapat merangsang pertumbuhan dan aktivitas bakteri A. xylinum. $\mathrm{pH}$ media diatur hingga mencapai $\mathrm{pH} 4$ dengan menambahkan asam asetat glasial. Tingkat keasaman ini merupakan $\mathrm{pH}$ optimum pertumbuhan bakteri dan dapat menghambat pertumbuhan jamur yang dapat mengkontaminasi media. Media kemudian diinokulasi dengan starter bakteri dan diinkubasi atau diperam selama 8 hari dalam wadah yang memiliki permukaan luas dan telah disterilisasi. Starter adalah strain murni A. xylinum yang dibiakkan pada suatu media cair. Penambahan starter juga dimaksudkan untuk mengurangi pencemaran yang dapat disebabkan oleh adanya bakteri pembusuk serta untuk mempercepat pembentukan nata (Sutarminingsih, 2004). Penggunaan wadah yang memiliki permukaan luas bertujuan agar pertukaran oksigen dapat berlangsung dengan baik, karena bakteri A. xylinum bersifat aerob. Bakteri
A.xylinum sensitif terhadap perubahan sifat-sifat fisik dan kimia lingkungannya sehingga wadah yang digunakan harus steril.

Bakteri pembentuk nata, yaitu $A$. xylinum jika ditumbuhkan dalam medium yang mengandung gula, dapat mengubah glukosa menjadi selulosa. Selulosa tersebut berupa benang-benang yang bersama-sama dengan polisakarida berlendir membentuk suatu jalinan seperti tekstil. Semakin lama waktu inkubasi lapisan ini akan semakin menebal, setelah masa pemeraman selama 8 hari, lapisan atau lembaran nata de coco mencapai sekitar $1 \mathrm{~cm}$. Lapisan ini bersifat sangat asam baik bau, cita rasa, maupun $\mathrm{pH}$-nya.

\section{Membran Nata de coco}

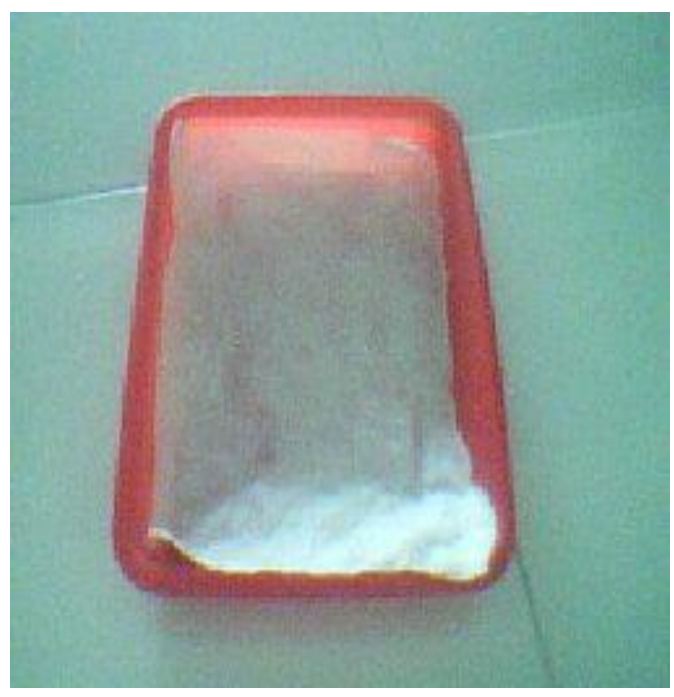

Gambar 1. Membran Nata de coco

Nata de coco hasil fermentasi yang berupa gel dicuci dengan air mengalir untuk menghilangkan bau dan rasa asam. Nata tersebut dimurnikan dengan larutan $\mathrm{NaOH} 2 \%$ untuk menghilangkan sisa bakteri A.xylinum. Proses selanjutnya nata direndam dalam larutan asam asetat glacial selama 1 jam untuk menurunkan $\mathrm{pH}$ yang naik akibat penambahan larutan $\mathrm{NaOH} 2 \%$. Nata dicuci kembali dengan air mengalir hingga $\mathrm{pH}$ netral dan nata de coco 
menjadi tawar. Nata yang telah tawar ini ditekan dengan alat hand-press hingga diperoleh membran nata de coco (Gambar 1). Proses penekanan ini bertujuan untuk mengurangi ketebalan membran dan menyebabkan berkurangnya kandungan air pada membran. Purwadi dan Mustika (2004) menyatakan bahwa nata de coco mengandung air sekitar 96-98 \%. Pengeringan pada suhu kamar betujuan untuk mengeringkan membran secara perlahan-lahan agar tidak merusak tekstur membran dan tidak mengubah struktur pori-pori membran.

\section{Karakteristik Membran}

Pengukuran karakteristik ini dilakukan dengan sistem aliran dead-end menggunakan sel ultrafiltrasi buntu berpengaduk, pengaduk magnetik, dan pompa udara atau kompresor. Sistem aliran dead-end adalah proses pemisahan yang mengalirkan umpan secara tegak lurus pada membran. Kelemahan sistem ini adalah adanya fenomena fouling atau polarisasi konsentrasi karena cepat terjadinya penyumbatan pada pori-pori membran akibat adanya tekanan dan pengaruh gaya gravitasi.

\section{Berat Jenis Membran}

Hasil pengujian berat jenis membran ini didapat nilai sebesar 0,6314 $\mathrm{g} / \mathrm{cm}^{3}$. Harga berat jenis membran menunjukkan kerapatan struktur pada membran. Berat jenis yang tinggi menunjukkan struktur yang rapat, sedangkan berat jenis yang rendah menunjukkan struktur yang kurang rapat. Berat jenis yang tinggi menyebabkan proses difusi air ke dalam membran nata de coco lebih sulit.

Berat jenis membran mempengaruhi nilai parameter karakterisasi membran, yaitu nilai fluks (permeabilitas) dan koefisien rejeksi (selektivitas). Berat jenis berbanding lurus dengan koefisien rejeksi dan berbanding terbalik dengan fluks. Berat jenis yang tinggi menyebabkan rendahnya nilai fluks karena kerapatan membran sangat tinggi sehingga poripori yang dimiliki membran semakin sedikit. Hal ini menyebabkan kemampuan umpan untuk melewati poripori membran menjadi rendah. Berat jenis yang tinggi menyebabkan tingginya nilai koefisien rejeksi. Membran dengan kerapatan yang tinggi akan memiliki kemampuan yang tinggi untuk menahan atau melewatkan spesi tertentu dari spesi yang lain.

\section{Fluks Membran}

Permeabilitas adalah ukuran kecepatan dari suatu spesi untuk melewati membran. Permeabilitas dinyatakan sebagai besaran fluks (J). Fluks dinyatakan oleh banyaknya volume permeat yang melewati membran setiap satuan luas permukaan membran per satuan waktu. Pengukuran fluks air, minyak dan larutan dekstran dilakukan pada tekanan 4 atm. Larutan umpan dimasukkan ke dalam sel ultrafiltrasi kemudian dialirkan pada membran dengan bantuan tekanan. Nilai fluks dipengaruhi oleh adanya proses pengadukan dan pemberian tekanan. Pengadukan berfungsi memobilisasi larutan yang bertujuan untuk meningkatkan difusivitas. Pengadukan juga berfungsi untuk menghindari terjadinya pengendapan maupun penumpukan zat terlarut pada permukaan membran (fouling). Tekanan berfungsi untuk memberikan gaya dorong yang lebih besar terhadap larutan untuk melewati membran dibandingkan hanya dengan mengandalkan gaya gravitasi. Nilai fluks diukur hingga volume permeat mencapai konstan. Nilai fluks pada volume yang konstan ini diambil sebagai nilai permeabilitas membran. 


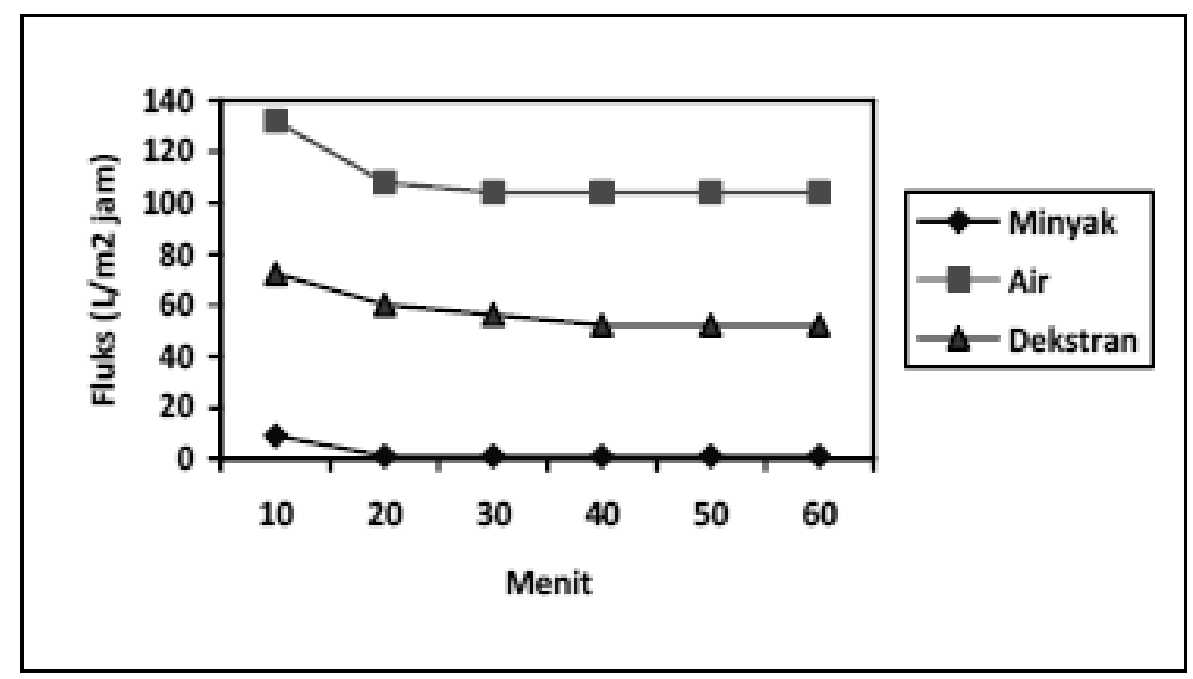

Gambar 2. Grafik fluks air, minyak dan dekstran

Besarnya nilai fluks pada air, minyak dan dekstran diperlihatkan pada Gambar 2. Fluks air dimulai pada $132,026 \mathrm{~L} / \mathrm{m}^{2}$ jam kemudian fluks turun menjadi $108,022 \mathrm{~L} / \mathrm{m}^{2}$ jam pada 10 menit kedua, lalu turun dan mencapai nilai konstan sebesar 104,021 L/m ${ }^{2}$ jam pada 10 menit ketiga hingga keenam. Fluks minyak dimulai pada $9,036 \mathrm{~L} / \mathrm{m}^{2}$ jam kemudian fluks turun mencapai nilai konstan sebesar $1,004 \mathrm{~L} / \mathrm{m}^{2}$ jam pada 10 menit kedua hingga keenam. Fluks dekstran dimulai pada 72,289 L.m ${ }^{2} / \mathrm{jam}$ kemudian fluks turun menjadi 60,240 L. $\mathrm{m}^{2} / \mathrm{jam}$ pada 10 menit kedua. Fluks turun lagi menjadi 56,224 L. $\mathrm{m}^{2} /$ jam pada 10 menit ketiga dan fluks mencapai nilai konstan sebesar 52,208 L.m2/jam pada 10 menit keempat hingga keenam. Nilai fluks yang konstan dijadikan sebagai nilai fluks dari membran nata de coco. Nilai fluks yang dihasilkan menunjukkan permeabilitas terhadap masing-masing larutan. Nilai fluks terbesar didapat pada air dan yang paling kecil didapat pada minyak. Hal ini disebabkan oleh berat molekul dekstran dan minyak jelantah lebih besar dibanding berat molekul air. Dekstran T-500 memiliki berat molekul sebesar $500.000 \mathrm{~g} / \mathrm{mol}$ sedangkan berat molekul minyak jelantah sebesar 860 $\mathrm{g} / \mathrm{mol}$.

\section{Rejeksi Membran}

Selektivitas merupakan ukuran kemampuan membran untuk menahan atau melewatkan spesi tertentu dari spesi yang lain. Penentuan selektivitas dapat menggunakan senyawa seperti dekstran, polietilen glikol, garam, gula, protein dan sebagainya (Radiman, 2008). Uji rejeksi pada penelitian ini menggunakan larutan dekstran T-500. Pengukuran rejeksi dilakukan dengan melewatkan larutan dekstran pada membran. Permeat dan umpan diukur serapannya dengan alat spektrofotometer.

Nilai rejeksi yang didapat dari penelitian ini hanya sebesar $15,11 \%$. Nilai rejeksi yang kecil disebabkan banyaknya molekul larutan yang tidak tertahan oleh membran dan lolos sebagai permeat. Nilai rejeksi juga dipengaruhi oleh nilai fluks yang tinggi. Nilai fluks berbanding terbalik dengan nilai rejeksi karena semakin tinggi nilai fluks atau permeabilitas suatu larutan pada membran maka menunjukkan banyaknya molekul-molekul yang dapat melewati membrane sehingga menyebabkan rendahnya nilai rejeksi. Hasil uji rejeksi dekstran T-500 dapat dilihat pada Tabel 1. 
Tabel 1. Hasil uji rejeksi membran nata de coco

\begin{tabular}{|c|c|c|}
\hline No. & $\begin{array}{c}\text { Konsentrasi Umpan } \\
\text { (ppm) }\end{array}$ & $\begin{array}{c}\text { Konsentrasi Permeat } \\
\text { (ppm) }\end{array}$ \\
\hline Dekstran T-500 & 660,48402 & 560,70109 \\
\hline Nilai \% Rejeksi & \multicolumn{2}{|c|}{$15,11 \%$} \\
\hline
\end{tabular}

\section{Kualitas Minyak Hasil Rekoveri}

Minyak goreng yang telah dipakai berulang kali akan menghasilkan warna yang lebih gelap dari sebelumnya. Minyak ini mengalami penurunan kualitas baik dari segi fisik atau kimianya. Secara kimia, kualitas minyak jelantah dapat dilihat dari angka asam, kadar air, angka penyabunan dan angka iod. Sedangkan secara fisik dapat dilihat dari warnanya. Warna suatu minyak disebabkan oleh zat warna alami yang dimiliki oleh minyak yang ikut terbawa suatu minyak pada saat pembuatan, zat warna tersebut antara lain alfa dan beta karoten, xanthofil, klorofil dan anthosianin. Kandungan zat warna alami tersebut menyebabkan warna suatu minyak bervariasi mulai dari kuning hingga kuning kemerahan. Minyak yang digunakan berkali-kali dapat mengalami perubahan warna menjadi semakin gelap. Hal ini disebabkan oleh oksidasi minyak pada saat penggorengan, selain itu juga senyawa warna pada bahan yang digoreng yang ikut terlarut juga menyebabkan warna minyak semakin gelap.

Membran nata de coco memiliki kemampuan untuk memperbaiki kualitas minyak jelantah dilihat dari warna minyak jelantah hasil rekoveri menjadi lebih cerah dibanding minyak jelantah yang belum direkoveri. Hal ini dikarenakan tidak terlewatkannya koloid, partikel, senyawa warna ataupun padatan-padatan pada minyak jelantah yang telah difiltrasi sehingga minyak jelantah hasil filtrasi memiliki suspensi partikel yang rendah. Minyak jelantah sebelum dan setelah direkoveri menggunakan membran nata de coco dapat dilihat pada Gambar 3

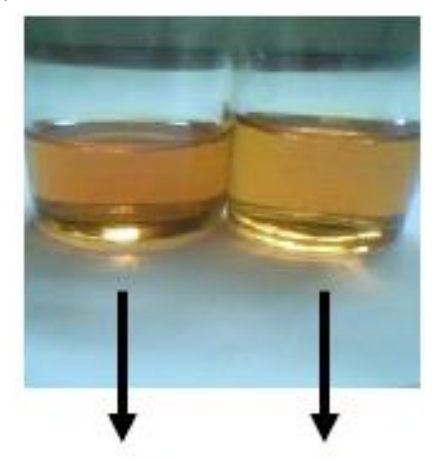

A B

Gambar 3. Minyak jelantah sebelum (A) dan setelah direkoveri

\section{Bilangan Asam}

Bilangan asam adalah jumlah milligram $\mathrm{KOH}$ yang dibutuhkan untuk menetralkan asam-asam lemak bebas dari satu gram minyak atau lemak. Hasil penelitian terhadap angka asam minyak jelantah hasil rekoveri menunjukkan adanya perbaikan kualitas minyak jelantah. Hal ini dapat dilihat dari nilai angka asam yang turun setelah direkoveri menggunakan membran nata de coco. Angka asam yang diperoleh pada minyak jelantah sebelum rekoveri sebesar 1,095\% sedangkan angka asam lemak bebas yang diperoleh pada minyak jelantah setelah direkoveri sebesar $0,493 \%$. Angka asam mengalami penurunan sebesar $54,95 \%$.

Angka asam berfungsi untuk mengetahui adanya asam lemak bebas hasil hidrolisis karena minyak yang terhidrolisis akan menghasilkan asam lemak bebas. Minyak goreng yang telah dipanaskan atau digunakan untuk menggoreng akan mengalami kenaikan angka asam. Kenaikan angka asam ini menandakan bahwa kualitas minyak tersebut menurun. Hal ini terjadi karena 
adanya peristiwa hidrolisis. Faktor yang menyebabkan terhidrolisisnya minyak adalah air yang dapat berasal dari minyak dan bahan makanan yang diolah. Proses hidrolisis ini tidak menyebabkan terjadinya perubahan komposisi asam lemak pada minyak. Ritonga (2004) menyatakan bahwa komposisi asam lemak yang dihasilkan dari proses hidrolisis adalah sama dengan komposisi asam lemak pada minyak goreng sebelum mengalami hidrolisis. Asam lemak bebas tidak hanya dihasilkan oleh proses hidrolisis. Asam lemak bebas juga dapat terbentuk selama proses oksidasi yang dihasilkan dari pemecahan dan oksidasi ikatan rangkap.

\section{Kadar Air}

Kadar air dihitung dengan menghitung selisih antara berat minyak awal dengan berat minyak akhir kemudian dibagi dengan berat minyak awal. Hasil yang diperoleh dari penelitian ini sebesar $0,059 \%$ untuk minyak yang telah direkoveri dan $0,87 \%$ untuk minyak yang belum direkoveri. Air merupakan kotoran yang tidak larut dalam minyak. Kotoran yang tidak larut ini dapat dipisahkan dengan cara filtrasi atau penyaringan. Filtrasi dengan membran nata de coco mampu mengurangi kadar air dalam minyak sebesar 93,22\%. Hal ini dikarenakan ketika partikel lewat mendekati pori-pori membran ada kemungkinan sebagian partikel akan bersentuhan dengan matriks membran dan partikel tersebut akan terperangkap atau terikat pada permukaan membran sehingga tidak dapat lolos melewati membran.

Membran nata de coco merupakan membran yang terbuat dari selulosa sehingga memiliki gugus hidroksil yang menjadikannya bersifat polar. Sifat polaritas ini menyebabkan membran memiliki kemampuan yang sangat baik untuk mengikat air yang ada pada minyak goreng. Minyak dengan kadar air rendah akan menghambat laju pembentukan asam lemak bebas dan oksidasi sehingga minyak terhindar dari kerusakan. Proses filtrasi dengan membran sangat baik untuk menurunkan kadar air pada minyak jelantah.

\section{Angka Penyabunan}

Bilangan penyabunan ialah jumlah alkali yang dibutuhkan untuk menyabunkan sejumlah contoh minyak. Bilangan penyabunan dinyatakan dalam jumlah milligram kalium hidroksida yang dibutuhkan untuk menyabunkan 1 gram minyak atau lemak. Minyak yang tersusun oleh asam lemak rantai C pendek berarti mempunyai berat molekul relatif kecil yang akan mempunyai angka penyabunan yang besar.

Angka penyabunan pada minyak jelantah sebelum rekoveri menunjukkan hasil sebesar 93 sedangkan angka penyabunan pada minyak jelantah yang telah direkoveri sebesar 120,054. Angka penyabunan meningkat sebesar 29,09\% setelah direkoveri, hal ini dikarenakan pada proses filtrasi dengan membran telah mengurangi jumlah pengotor dalam minyak yang menyebabkan jumlah pengotor dalam minyak rekoveri berkurang.

\section{Angka Iod}

Angka iod merupakan jumlah iod yang diserap dan menunjukkan banyaknya ikatan rangkap atau ketidakjenuhan asam lemak dalam minyak. Semakin tinggi angka iod menunjukkan semakin banyak ikatan rangkap yang terdapat dalam minyak. Semakin banyak ikatan rangkap yang dimiliki, maka semakin tinggi tingkat ketidakjenuhan suatu minyak. Sebaliknya, angka iod yang kecil menunjukkan sedikitnya ikatan rangkap yang dimiliki oleh minyak, tingkat ketidakjenuhannya semakin rendah. 
Minyak dapat mengalami kerusakan akibat peristiwa oksidasi ketika disimpan atau dipanaskan. Minyak pada saat penyimpanan mengalami peristiwa oksidasi karena adanya kontak dengan udara. Bila dibandingkan dengan minyak yang mengalami kerusakan pada saat penyimpanan maka pada proses penggorengan kerusakan minyak akan lebih cepat terjadi. Selama proses penggorengan minyak akan mengalami banyak pemutusan ikatan rangkap pada asam lemak tak jenuhnya akibat panas.

Selama proses pemanasan minyak akan mengalami perubahan kimia yaitu berupa pembentukan peroksida dalam asam lemak tak jenuh. Asam lemak tak jenuh dapat mengikat oksigen pada ikatan rangkapnya sehingga membentuk peroksida. Penggunaan minyak yang berulang-ulang dapat menyebabkan ikatan rangkap teroksidasi. Peristiwa oksidasi ini dapat menyebabkan pemutusan ikatan rangkap pada asam lemak tak jenuh, sehingga angka iod suatu minyak terjadi penurunan. Angka iod yang kecil menunjukkan kualitas suatu minyak goreng juga rendah. Angka iod yang diperoleh pada minyak sebelum rekoveri sebesar $28,62 \mathrm{mg}$ iod $/ 100 \mathrm{~g}$ dan angka iod pada minyak yang telah direkoveri sebesar $30,95 \mathrm{mg}$ iod/100g. Proses rekoveri menggunakan membran hanya sedikit meningkatkan angka iod yang terdapat pada minyak tersebut yaitu sebesar $8,14 \%$. Meningkatnya angka iod ini disebabkan telah terpisahnya zat-zat yang tidak diinginkan, seperti pengotor dan air oleh membran nata de coco.

\section{KESIMPULAN}

Membran nata de coco mampu untuk merekoveri minyak jelantah. Minyak jelantah hasil rekoveri mengalami peningkatan kualitas dibanding sebelum rekoveri dilihat dari pengurangan bilangan asam menjadi
0,493 \% dan kadar air 0,059 \%, serta peningkatan angka penyabunan menjadi sebesar 120,054 mg KOH/ g dan angka iod $30,95 \mathrm{mg}$ iod/100 g.

\section{DAFTAR PUSTAKA}

Agustina, A., Sri Pudji R., Tri Widianto., dan Trisni .A., 2008, Penggunaan Teknologi Membran pada Pengolahan Air Limbah Industri Kelapa Sawit, Workshop Teknologi Industri Kimia dan Kemasan.

Dalimunthe, NA., 2008, Pemanfaatan Minyak goreng Bekas Menjadi Sabun Mandi Padat, Universitas Sumatera Utara, Medan.

Krystynowicz, 2001, Biosynthesis of Bacterial Cellulose and its Potential Application In The Different Industries, (online), http://www.biotecnology.pl.com/sc ience/krystynomcz.htm., diakses tanggal 24 Maret 2009.

Miyagi, A., S. Rangaswamy, N. Mitsutoshi, 2003, Membrane and Additional Adsorption Processes for Quality Improvement of Used Frying Oils, JAOCS, Vol.80, No.9.

Piluharto, B., 2003, Kajian Sifat Fisik Film Tipis Nata de coco sebagai Membran Ultrafiltrasi, Jurnal Ilmu Dasar, Volume 4, Nomor 1, hal 52-57.

Purwadi dan Nanti Mustika, 2004, Teknologi Agroindustri Kelapa yang Sesuai untuk Pedesaan, Prosiding Konferensi Nasional Kelapa IV, Bandar Lampung.

Radiman, C.L, S. Widyaningsih, S. Sugesty, 2008, New Application of Kenaf (Hibiscus cannabinus L) as microfiltration membranes, Journal of Membrane Science, Vol.315, $141-146$. 
Molekul, Vol. 8. No. 1. Mei, 2013: 20 - 30

Ritonga, M.Y., 2004, Pengaruh Bilangan Asam terhadap Hidrolisa Minyak Kelapa Sawit, Fakultas Teknik USU, Medan.
Sutarminingsih, Ch.L., 2004, Peluang Usaha Nata de coco, Kanisius, Yogyakarta. 